\title{
Brain injury biomarkers and inflammatory markers like pronostic factors on mortality in patients with spontaneous intracranial hemorrhage (medical-adults intensive care)
}

DL Aguillón Prada*, A Serrano Lázaro, RC Huerta Bravo, A Mesejo Arizmendi, JM Segura Roca, JC Sanchis Miñana, C Sanchis Piqueras, J Romero Guía, M Rodriguez Gimillo

From ESICM LIVES 2015

Berlin, Germany. 3-7 October 2015

\section{Objective}

To value the usefulness of brain injury biomarkers (BIB) and inflammatory markers (IM) to predict mortality in spontaneous intracranial hemorrhage patients $(\mathrm{SIH})$.

\section{Material and Methods}

BIB (D Dimer (DD), BNP and CRP) were determined at admission, 1, 2, 3 and 7th day; IM at admission and 7th day. Descriptive analysis \% and Median (minimal/ maximum). Independent samples $\mathrm{T}$-student to compare means $(\mathrm{p}<0.05)$. A binary logistic multivariate regression analysis was performed (95\% CI OR).

\section{Results}

103 patients with SIH. 66\% were men. Age $61.8( \pm 12.7)$. Overall Mortallity 37\%. ICU stay 7 days (1-55). Glasgow Coma Scale 12 (3-15). SIH 20.18 cc volume (1-252).

The univariate correlation between of BIB and MI with mortality in Table 1 . In mutivariate analysis: protective factors were BNP at admission (OR 1.1, 95\% CI 1.1-1.2 (p $0.02)$ ), DD at 7th day (OR 1.1, 95\% CI 1.1-1.3 (p 0.009)) and Prealbumin at 7th day (OR 0.9, 95\% CI 0.8-0.9 (p 0.03)).

\section{Conclusions}

BNP at admission, $24 \mathrm{~h}$ and $48 \mathrm{~h}$ and DD as late marker at $48 \mathrm{~h}, 72 \mathrm{~h}$ and 7 th day were correlated with mortality

Table 1. Relationship brain injury biomarkers and inflammatory markers with mortality; Median \pm SD. BIB: Brain injury biomarkers; IM: Inflammatory markers; BNP: Brain natriuretic peptide; DD: D Dimer

\begin{tabular}{lllll}
\hline BIB and IM & & Dead & Alive & P \\
\hline BNP $(\mathrm{pg} / \mathrm{ml})$ & Admission & $223,5 \pm 318,46$ & $82.41 \pm 95,55$ & 0,001 \\
\hline & $24 \mathrm{~h}$ & $175,96 \pm 202,08$ & $87.84 \pm 77,19$ & 0,002 \\
\hline DD $(\mu \mathrm{g} / \mathrm{L})$ & $48 \mathrm{~h}$ & $142.32 \pm 156,01$ & $94.12 \pm 82,66$ & 0,04 \\
\hline & $48 \mathrm{~h}$ & $1915,8 \pm 1631,5$ & $883,7 \pm 1368,6$ & 0,001 \\
\hline Leukocytosis & $72 \mathrm{~h}$ & $2525,27 \pm 2142,47$ & $1051.92 \pm 1254,15$ & 0,000 \\
\hline Albumin $(\mathrm{g} / \mathrm{dl})$ & th d & $3677.07 \pm 2224,72$ & $2150.9 \pm 1820,42$ & 0,005 \\
\hline Prealbúmin $(\mathrm{mg} / \mathrm{dl})$ & Admission & $12037,5 \pm 4806,8$ & $10241,8 \pm 3624,2$ & 0,03 \\
\hline
\end{tabular}


in patients with SIH. IM correlated with mortality: leukocytosis, albumin and prealbumin at admission and prealbumin, ferritin and haptoglobin at 7th day.

Multivariate analysis found significance for increased risk of death BNP at admission and DD at 7th day; and protective factor was Prealbumin at 7 th day.

Published: 1 October 2015

doi:10.1186/2197-425X-3-S1-A852

Cite this article as: Aguillón Prada et al:: Brain injury biomarkers and inflammatory markers like pronostic factors on mortality in patients with spontaneous intracranial hemorrhage (medical-adults intensive care). Intensive Care Medicine Experimental 2015 3(Suppl 1):A852.

\section{Submit your manuscript to a SpringerOpen ${ }^{\circ}$ journal and benefit from:}

- Convenient online submission

- Rigorous peer review

- Immediate publication on acceptance

- Open access: articles freely available online

- High visibility within the field

- Retaining the copyright to your article 